\title{
5237 Sayılı Türk Ceza Kanunu'nda Kısırlaştırma Suçu
}

\author{
Hüseyin Ertuğrul \\ Kırşehir Ahi Evran Üniversitesi, İktisadi ve İdari Bilimler Fakültesi, Kırşehir \\ hertugrul83@ahievran.edu.tr \\ ORCID ID: https://orcid.org/0000-0003-1372-2451
}

$\begin{array}{lllll}\text { Derleme } & \\ \text { Geliş Tarihi: } & 25.05 .2017 & \text { Revize Tarihi: } 22.06 .2018 & \text { Kabul Tarihi: } & 22.06 .2018\end{array}$

\author{
Atıf Bilgisi \\ Ertuğrul, H. (2018). 5237 sayılı türk ceza kanunu'nda kısırlaştırma suçu, Ahi Evran Üniversitesi Sosyal Bilimler \\ Enstitüsü Dergisi, 4(1), 59-74. Doi: 10.31592/aeusbed.315933
}

\begin{abstract}
ÖZ
Bir insanın üreme ve neslini devam ettirebilme hakkı, onun yaşama hakkı kadar temel bir hakkıdır. Çünkü üreme hakkına sahip kişilerin neslini devam ettirebilmesiyle insanlar yaşama hakkına sahip olabileceklerdir. Başka bir ifadeyle, üreme hakkının kullanılamamasıyla neslin devamı sağlanamayacağından, yaşama hakkı da işlevsiz hale gelecektir. $\mathrm{Bu}$ mülahazalarla, ceza kanunlarında üreme hakkını korumaya yönelik kısırlaştırma fiillerine yönelik suç tanımları düzenlenmektedir. 5237 sayılı Türk Ceza Kanunu'nun 101. maddesinde düzenlenen kısırlaştırma suçu, üreme hakkını teminat altına almakla birlikte, öğretide bu düzenlemenin yetersiz kaldığı da ifade edilmektedir. Bu suç tanımına, gerek hadımlaştırmanın eklenmesi gerektiği; gerekse de, suçun kanuni tanımın kanun tekniğine uygun olmadığı yönünde eleştiriler getirilmektedir. Bununla birlikte, 2827 sayılı Nüfus Planlaması Hakkında Kanun'da her ergin kişiye kısırlaşma hakkı tanınmaktadır. İşte bu hakkın korunması için, kişinin rızasız kısırlaştırılması veya rızası bulunsa dahi, yetkisiz kişilerle bu fiilin işlenmesi durumu, Türk Ceza Kanunu'nda kısırlaştırma suçu olarak düzenlenmiştir. Çalışmamızda bu suçun maddi manevi unsurları incelenerek uygulama ve teori açısından eksik hususları ve çözüm önerileri üzerinde durulmaya çalışılmıştır. Bu hususların göz önünde bulundurulup suçun kanuni tanımının yeniden düzenlenmesi gerekmektedir.

Anahtar Kelimeler: Sterilizasyon, üreme hakkı, rıza
\end{abstract}

\section{Sterilization Crimes In Turkish Penal Code No 5237}

\begin{abstract}
The right of a person to continue reproduction and generation is as fundamental as the right to life. Because people who have the right to reproductive can continue their generation, they will have the right to live. In other words, the right to life will also become dysfunctional, since the survival of the right to reproductive failure can not be ensured. With these considerations, crime definitions for the acts of sterilization to protect the reproductive right in criminal law are organized. It is also stated that the sterilization crime, which is organized in Article 101 of the Turkish Criminal Code numbered 5237, guarantees the right to reproduction and that this regulation of the teaching has been inadequate. For the definition of this crime, it is necessary that the castration should be added; criticism has been made that the legal definition of the crime does not comply with the law. However, the Population Planning Law no. 2827 gives the right to sterilize every adult person. Here, for the protection of this right, even if the person is unwittingly sterilized or resigned, the fact that this act is committed by unauthorized persons is regulated as a terrorizing act in the Turkish Criminal Code. In this study, the material and moral elements of this crime were examined and tried to focus on the missing aspects and solution proposal in terms of application and theory. It is necessary to consider these points and to rearrange the legal definition of the crime.
\end{abstract}

Key words: Sterlization, reproductive right, consent

\section{Giriş}

Kısırlaştırma fiili, kişilerin çocuk sahibi olmasına ve neslini devam ettirmesine engel bir niteliğe haizdir. Dolayısıyla ceza kanunlarında düzenlenen kısırlaştırma suçu tanımları, neslin devamını teminat altına alan ve sağlıklı bireylerin yetişmesine vesile olan suç tanımlarıdır. Gerçekten de bir neslin devamı ancak kişilerin güvenli bir şekilde dünyaya gelmeleriyle ve güvenli bir şekilde üreme haklarına sahip olmalarıyla mümkündür. Dolayısıyla iradesiyle bile olsa kişilerin üreme hakkından kolayca feragat edebilmesi, o toplumun geleceğini de yakından etkilemektedir. 
Bu mülahazalarla, mevcut ceza kanunumuzda kısırlaştırma fiili suç olarak düzenlenmiştir. Söz konusu suçun maddi ve manevi unsurlarına yönelik teori ve pratikte birçok eleştiri yöneltilmektedir. Özellikle kısırlaşmak isteyen bireylerin danışman görüşü almadan rızalarının alınması veya belirli bir düşünme süresinin kişilere verilmesi ya da kısırlaştırma fiilinin seçimlik hareketlerinin artırılması hususlarıdır.

Türk ceza hukuku sistematiğine göre özellikle suçun maddi ve manevi unsurları ve muhakeme süreci ve yaptırım şekli açısından suçun analizi apılmıştır. Çalışmada öncelikle kısırlaştırma, cerrahi kısırlaştırma ve hadımaştırma gibi temel kavramlar açıklanmıştır. Daha sonra tarihsel süreçte Türk Hukuk mevzuatında kısırlaştırma suçuyla ilgili düzenlemeler incelenmiştir. Çalışmada son olarak Türk ceza hukukuna görekısırlaştırma suçu, suçun maddi ve manevi unsurları, muhakeme süreci ve yaptırım şekli açısından değerlendirilmiştir. Bu değerlendirme neticesinde kanaatimizce, suçun kanuni tanımının söz konusu eleştiri ve tartışmalar dikkate alınarak, kanun tekniğine uygun bir şekilde yeniden düzenlenmesi gerekmektedir. Özellikle kısırlaştırma fiilinin geçici ve kalıcılığının suçun kanuni tanımında vurgulanması hususunun önemli faydalar barındırdığını düşünmekteyiz.

\section{Kavramsal Çerçeve}

Burada "kısırlaştırma" ve onun ağırlaşmış şekli olan "hadımlaştırma" kavramlarını tanımlamak, konunun anlaşılması açısından büyük önem arz etmektedir.

\section{Kısırlaştırma Kavramı (Sterilizasyon)}

"Kısırlaştırma" veya yaygın ifadesiyle "sterilizasyon", erkek ya da kadının, ameliyatla üreme yeteneğinin ortadan kaldırılmasını (infertil hale getirilmesini) ifade etmektedir (Temel, 2010, s.62). Bu işlemde üreme yeteneği ortadan kaldırılmakla birlikte, cinsel dürtüler bertaraf edilmemektedir. Yani kısırlaştırma işleminde, üreme yeteneği ortadan kalkarken, kişinin cinsel arzuları ve istekleri devam etmektedir (Alpaslan, 2012).

Günümüzde sterilizasyon, çiftler için en yaygın doğum kontrol biçimlerinden birisidir. Bilgilendirilip rızası ile uygun klinik standartlara göre yapıldığında, doğurganlığg kalıcı olarak kontrol etme anlamında güvenilir ve etkili bir yöntemdir (Shih, Turok ve Parker, 2011).

Öğretide her ne kadar, kısırlaştırma işlemiyle, üreme yeteneği geri dönüşü olmaksızın kaybedildiği ifade edilse de (Hakeri, 2015), günümüz tıp teknolojisinde tekrar üreme yeteneğinin kazanıldığının örnekleri mevcuttur. Bu tıbbi işlem, iki şekilde gerçekleştirilmektedir: 'Cerrahi kısırlaştırma' ve 'kimyasal kısırlaştırma'.

\section{Cerrahi Kısırlaştırma}

Cerrahi kısırlaştırma işlemini erkek ve kadında ayrı uygulandığından iki ayrı başlık altında incelemek gerekmektedir.

\section{Erkekte Cerrahi Kısırlaştırma (Vazektomi)}

Erkeklerde cerrahi kısırlaştırma, 'vazektomi' (tüplerin bağlanması/kordon bağlama) yöntemiyle gerçekleştirilmektedir. Bu yöntemle, sperm kanalı cerrahi müdahale ile kesilerek, testislerden idrar kanalına sperm transferi engellenmektedir. Yine bu yöntemde, sperm kanalları iki ucundan kesilmekte ve kesilen uçlar bağlanmakta veya elektrikli isıtıcılar yardımıyla tıkanmaktadır.

\section{Kadında Cerrahi Kısırlaştırma (Tüp Ligasyonu)}

Kadınlarda cerrahi kısırlaştırma ise, 'tüp ligasyonu' (tüplerin bağlanması / tubal sterilizasyon) denilen bir cerrahi müdahale ile gerçekleştirilmektedir. Bu ameliyatla tüpler, yani yumurta kanalı bağlanarak, yumurtanın rahime ulaşması ve sperm hücresinin yumurta hücresiyle birleşmesi engellenmektedir (Temel, 2010). 
Gerek "vazektomi” gerekse de, "tüp ligasyonu” işleminde, kısırlaştırılacak kişinin yeterince aydınlatılmış olması, önem arz etmektedir. Çünkü her iki işlemin önemli yan etkileri olduğu tıbbi bir gerçektir. Özellikle, kalp hastalığı, solunum yetmezliği, hipertansiyon, diyabet, pıhtılaşma bozukluğu, anemi ve obezite rahatsızlıklarına sahip hastalar için, kısırlaştırma işlemi ilk seçenek olmaması gerektiği ve eğer olursa karşılaşılabilecek komplikasyonlar açıkça kişiye ifade edilmelidir. Örneğin, emziren bir anne için, tüp ligasyonu yaptırmanın, kullanılan anestezik maddenin anne sütüne geçmesinden bahisle, bebeği etkileyeceği açikça ifade edilmelidir (Erşahin, 2002).

\section{Kimyasal Kısırlaştırma}

"Kimyasal kısırlaştırma", tarihte bir dönem önemli bulaşıcı hastalıkların yayılmasını önlemede bir tıbbi yöntem olarak uygulanmış olup (Mehtaji, Jadwani ve Goyal, 1977) vücuda verilen kimyasal maddeler marifetiyle kişinin üreme yeteneğinin sona ermesini sağlayan bir tıbbi işlemdir.

$\mathrm{Bu}$ işlem, kadınlarda rahim içerisine kimyasal etkili tabletler yerleştirilerek rahmin ve tüplerin yanma şeklinde tahrip edilmesi suretiyle icra edilirken; erkeklerde daha çok sperm üretimini durdurmaya yönelik aşılama kullanılarak gerçekleştirilmektedir. Dikkat edilirse, burada da, cinsel dürtüler bertaraf edilmemektedir. Kadında rahim veya tüpler tahrip edilmiş olsa da veya erkek de, sperm üretimi durdurulmuş olsa da, cinsel dürtüler varlığını kişide devam ettirmektedir. Fakat kullanılan kimyasal maddelerin yan etkilerinin çokluğundan dolayı çok tercih edilen bir yöntem değildir (Mehtaji, Jadwani ve Goyal, 1977).

\section{Hadımlaştırma Kavramı (Kastrasyon)}

Kısırlaştırma işlemine benzer, fakat ondan farklı olarak cinsel dürtülerin de üreme yeteneğiyle birlikte ortadan kaldırıldığı bir işlem vardır ki; ona da, 'hadımlık' veya tıbbi ifadesiyle 'kastrasyon' denilmektedir.

Hadımlaştırma işleminde, erkeklerde testisler, kadınlarda ise yumurtalıklar alınmakta ve kimyasal madde ve 1şınla tahrip edilmektedir. Bu tahrip sonucunda cinsel hormonlar olan östrojen ve testosteron hormonlarının üretimi sona erdiğinden, kısırlaştırmadan farklı olarak cinsel istek ve arzular da tamamen kaybedilmektedir. Görüleceği üzere hadımlaştırma, kısırlaştırmadan daha ağır bir işlem olup kendi içerisinde ikiye ayrılmaktadır: 'Cerrahi hadımlaştırma' ve 'kimyasal hadımlaştırma.'

\section{Cerrahi Hadımlaştırma}

"Cerrahi hadımlık", operasyonel bir işlemken genelde ilerlemiş prostat kanserinin daha da büyümesine engel olmak için kullanılmakta ve bu suretle testislerin veya yumurtalıkların ameliyat ile alınması işlemidir (Akbaba, 2009).

\section{Kimyasal Hadımlaștırma}

"Kimyasal hadımlık" ise, herhangi bir ameliyat gerektirmemekle birlikte, kullanılan birtakım ilaçların hormon üretimini durdurması şeklindeki bir tedavi yöntemidir. Yan etki olarak kadınlaşma bulguları içermesi dolayısıyla kabul görülmese de, günümüzde cinsel suç faillerinin bu işleme tabi tutulması tartışılmaktadır (Pastner, 2012; Yenidünya ve Yaşar, 2013).

\section{Tarihsel Süreç}

Türk Hukuk mevzuatımızdaki kısırlaştırma suçlarıyla ilgili düzenlemeleri ve hukuki gelişmeleri, dört ayrı dönemde incelememiz mümkündür.

\section{Boşluk Dönemi (1921-1936)}

Her ne kadar Cumhuriyet 1923'te ilan edilmiş olmasa da 1921 Anayasası yürürlükteyken bunun olması ve 1921 Anayasasıyla Türkiye Devleti'nin kurulduğunun öğreti de kabulünden bahisle (Tunç, Bilir ve Yavuz, 2009), Türkiye Cumhuriyeti Hukuk Sistemi'ni bu tarihte başlatmakta bir beis olmayacaktır. Bu ilk yıllarda kısırlaştırma suçları dâhil olmak üzere, suç ve cezalara ilişkin bir kanun 
yürürlüğe girmediğinden, 1926 tarihli Türk Ceza Kanunu kabul edilene dek, bu fiillerin cezai bir sorumluluğunun söz konusu olmadığını, dolayısıyla bu fiiller açısından mutlak bir serbestlik söz konusu olacağını kabul etmek gerekecektir.

Cumhuriyet tarihinin ilk ceza kanunu olan 01.03.1926'da kabul edilen ve 13.03.1926 tarih ve 320 sayılı Resmî Gazete'de yayımlanan mülga 765 sayılı Türk Ceza Kanunu'nun ilk halinde de 1936 değişikliğine kadar "kısırlaştırma" fiili suç olarak düzenlenmemişti. Fakat 1926 ile 1936 arası kısırlaştırma fiillerini kasten yaralama suçu (765 s. TCK'nın ilk hali, m.451 vd.) kapsamında değerlendirmek mümkündü.

\section{Yasak Dönemi (1936-1965)}

11.06.1936'da kabul edilen ve 23.06.1936 tarih ve 3337 sayılı Resmî Gazete'de yayımlanan 3038 sayılı Türk Ceza Kanunun Bazı Maddelerini Değiştiren Kanun ’la, suç tipleri ve unsurları önemli ölçüde değiştirilmiş ve kısırlaştırma fiili de ilk kez Türk Ceza Kanunu'na girmiştir. Kanunun 471. maddesinde "kısırlaştırma" fiilleri suç olarak düzenlenmiştir. Hatta bu fiillerin teşvik ve propogandası da ayrı bir suç tanımı olarak madde metninde yer almıştır (m.471/2). Yine bu düzenlemeyle, kısırlaştırma suçlarıyla birlikte çocuk düşürtme ve çocuk düşürme suçlarının da düzenlendiği dördüncü fasılın başlığı, "Kasten çocuk düşürmek ve düşürtmek cürümleri" yerine "Irkın tümlüğü ve sağlığı aleyhine cürümler" olarak değiştirilmiştir.

\section{Geçiş Dönemi (1965-1983)}

Bu dönemde sağlık hizmetlerindeki gelişmelere paralel olarak; çocuk ölümlerinin azalması, nüfusun yılda ortalama yüzde iki büyümesi ve özellikle 1960 yılı itibariyle nüfus artışının bugüne dek en yüksek seviyeye çıkması, nüfus artışının getireceği sosyal ve ekonomik problemlerden duyulan çekince, nüfus planlamasında politika değişikliğine yol açmıştır (Çokar, 2008). 01.04.1965 tarihinde kabul edilen ve 10.04.1965 tarih ve 11976 say1lı Resmî Gazete'de yayımlanan 557 sayılı Nüfus Planlanması Hakkında Kanun'la, tıbbi zaruret halinde kişilerin kısırlaştırılmasının mümkün olacağı düzenlenmiştir (Mülga NPHK, m. 3 ve 4). Buna göre, kişilerin kısırlaştırılması açısından, tıbbi zorunluluk olarak kişide mevcut bir hastalığın varlığı var ise, tedavinin sağlanması açısından kısırlaştırma fiili hukuka aykırı sayılmayacak, kişiler kısırlaştırılabilecektir.

Şu hâlde kısırlaştırma fiillerinde, bir tıbbi zorunluluğun varlığı durumunda failin cezai bir sorumluluğu olmayacakken, NPHK bu zorunluluğu görüp müdahalede bulunmayan yetkili hekim için de özel bir yaptırım öngörmüştür. Buna göre, "Bu kanunun 3. 4 ve 5. maddeleri (Tıbbi zaruret halinde sterilizasyon yapılması) hükümlerine aykırı fiil ve hareketlerde bulunanlar, TCK ile ceza hükümleri ihtiva eden diğer kanunlarda daha ă̆ır cezalar tayin edilmemişse 500 liradan 1000 liraya kadar ă̆ır para cezasina çarptırılırlar.” (Mülga NPHK, m. 7/1).

Mülga 765 s. TCK'da ise, tıbbi zorunluluk hali kısırlaştırma suçlarının kanuni tanımında ifade edilmese de genel zorunluluk halini düzenleyen 49. maddesi de mevcuttu. Buna göre, "Gerek nefsini ve gerek başkasını vukuuna bilerek mahal vermediği ve başka türlü tahaffüz imkanıda olmadığı ă̆ır ve muhakkak bir tehlikeden muhafaza etmek zaruretinin bais olduğu mecburiyetle, işlenilen fiillerden dolayı faile ceza verilemez." (Mülga TCK, m.49/1(3)) denilmişti. Dolayısıyla 765 s. TCK'nın ilk halinden mülga olmasına kadar yürürlükte olan bu maddesiyle, örneğin tıbbi zorunlukla kişilerin kısırlaştırılması durumunda, failin cezai sorumluluğu söz konusu olmayacaktır (Toroslu, 1968).

\section{Serbestlik Dönemi (1983’ten Günümüze)}

1983 yılı, 'kısırlaştırma hakkı'nın hukuk sistemimize girdiği yıl olması açısından önemli bir dönüm noktası olmuştur. Bu yılda yürürlüğe giren yeni NPHK ile verilen bu hakla, günümüze kadar gelinmiştir. Böylece her ergin kişi, kendinin kısırlaştırılmasını talep edebilecektir.

765 sayılı TCK yürürlükteyken, 27.05.1983 tarih ve 18059 sayılı Resmî Gazete'de yayımlanarak yürürlüğe giren 2827 sayılı NPHK'yla, 765 s. Kanunda yer alan kısırlaştırma suçları son kez değiştirilmiştir (2827 s. Kanun, m. 9-13). 
765 say1lı TCK mülga edilerek, 26.09.2004 tarihinde kabul edilen 12.10.2004 tarih ve 25611 sayılı Resmî Gazete'de yayımlanan ve 01.06.2005 tarihinde yürürlüğe giren Türk Ceza Kanunu'nuyla, kısırlaştırma fiilleri birer ayrı suç tipi olarak düzenlenmiş̧ir. Bu düzenlemeler, 2827 sayılı 'Nüfus Planlaması Hakkında Kanun'la genel itibariyle uyum içerisinde olduğunu söylemek mümkündür.

Esasen NPHK her ne kadar, evli bir kişinin kısırlaştırılmasında eşinin rızasını aramış olsa da (m. 6/2); TCK, eşinin rızasının bulunmamasını suçun bir unsuru olarak düzenlemediğinden, bu fiil de yaptırımsız kalmaktadır (m. 101). Hekim açısından, eşinden rızasını almaksızın yapılan kısırlaştırma işlemi için cezai sorumluluğu olmamakla birlikte, bir idari sorumluluğu pekâlâ söz konusu olabilecektir (Hakeri, 2012, s.96). Bunun dışında, kısırlaştırma işlemiyle ilgili bir ameliyatı yapacak hekimin müdahalesinde aşağıdaki şartlar yoksa ayrıca hukuki sorumluluğu da söz konusu olacaktır. $\mathrm{Bu}$ şartlar;

- Öncelikle ameliyatı gerçekleştirecek hekimin kanunen yetkili bir hekim olması (RTSHYDİT, m. 10/2,3),

- Ameliyat olacak kişinin yazılı rızası (RTSHYDİT, m. 13, 15),

- Bu ameliyat tıp biliminin verilerine uygun olması (Özgenç, 2015, s.355),

- Ameliyat olacak kişinin kendisine uygulanacak işlemle ilgili etki ve sonuçları bakımından yeterince bilgilendirilmiş (aydınlatılmış onam) olmasıdır (Özgenç, 2015; Akyıldız, 2010; Hakeri, 2015).

İşte bu dört şarttan birinin eksikliği dolayısıyla ilgili sağlık personelinin hukuki sorumluluğu gündeme gelecektir. Mesela sterilizasyon işleminde hekimin hastaya kısa bir müddet daha döllenme riskinin devam ettiği bilgisini vermeyerek kişinin çocuk sahibi olması durumunda hekimin aydınlatılmış onamda bulunmadığı ortadadır ve tazminat sorumluluğu (BK, m. $53 \mathrm{vd}$.) söz konusu olacaktır (Akyıldız, 2010). Ayrıca 28.04.2004 tarihli Türk Tabipleri Birliği Disiplin Yönetmeliği'ne göre, "hastanın aydınlatılmamış onamını usulüne uygun olmaksızın tıbbi girişimde bulunmak" para cezasını gerektirmektedir (TTBDY, m. 4/1(s)).

\section{Sayılı TCK’da Düzenlenen Kısırlaştırma Suçu}

5237 sayılı Türk Ceza Kanunun 101. maddesinde iki ayrı kısırlaştırma suçu düzenlenmiştir. Bu maddedeki düzenlemeyi şu şekilde ifade etmemiz mümkündür:

-Yetkili hekim tarafından rızasız kısırlaştırma suçu (m. 101/1, ilk cümle) ve bu suçun nitelikli hali (m. 101/1, ikinci cümle),

-Yetkisiz kişi tarafindan rızaya dayalı kısırlaştırma suçu (m. 101/2)'dur.

TCK'da düzenlenen kısırlaştırma fiilleriyle, mülga 765 sayılı TCK'da düzenlenen kısırlaştırma suçunu (m. 471, 472) karşılaştırdığımızda, yeni TCK'da öngörülen ceza miktarlarının yukarıya çekildiği görülmektedir. Gerçekten de kısırlaştırma suçunun rızasız yapılması, mülga TCK'da beş yıla kadar hapis cezasıyla cezalandırılırken (m. 471/1); yeni TCK'da bu süre altı yıl olarak belirlenmiştir. Rızaya dayalı kısırlaştırmada ise, öngörülen ceza miktarının üst sınırı hem mülga TCK'da (m. 471/2) hem de yeni TCK'da üç yıl olarak belirlenmiştir.

\section{Korunan Hukuksal Değer}

Öğretide, Tezcan, Erdem ve Önok (2014)'a göre bu suç düzenlemesi ile korunan hukuksal değer, kendi geleceğini belirleme hakk1 ve beden bütünlüğüdür. Hafızoğulları ve Özen (2015)'e göre ise, korunan hukuksal değer, kişinin kendini üreyerek devam ettirmesinin esen kılınmasına ilişkin çıkarıdır. Koca ve Üzülmez (2013) ise, bu suçla korunan hukuksal değeri, kişinin vücut bütünlüğü hakk1 ve üreme yeteneği yani kişilerin neslini devam ettirme hakkı olarak açıklamaktadır. Kiziroğlu (2013) ise, kişinin sağlık ve vücut bütünlügüyle birlikte kendi geleceğini belirleme hakkını korunan hukuksal değer içerisinde değerlendirmiştir. 
Kanaatimizce, kısırlaştırma suçunda korunan hukuksal değer, kişinin üreme hakkıdır ve dolayısıyla anne veya baba olabilme hakkıdır. Bu hakkın elinden alınması vücuda bir müdahaleyle olduğundan, kişinin vücut bütünlüğü hakkı da bu suç düzenlemesiyle korunmaktadır.

\section{Suçun Konusu}

Kısırlaştırma suçunun konusu, kısırlaştırılan kişinin üreme yeteneği fonksiyonunu sağlayan organ ve duyulardır (Koca ve Üzülmez, 2013). Dolayısıyla üreme yeteneğini kaybetmiş bir kişiye karşı bu suç işlenemeyecektir. Esasen, kişide üreme organı bulunup henüz bu fonksiyonu icra edecek düzeyde bulunmasa bile, bu kişiye karşı kısırlaştırma suçunun işlenebileceği kanaatindeyiz. Dolayısıyla henüz adet dönemine girmemiş bir kız çocuğu üreme yeteneğine haiz kabul edilecekken; menopoz dönemini bitirmiş bir kadının artık üreme yeteneğinden söz edilemez. Şu halde adet dönemindeki bir kız çocuğuna karşı kısırlaştırma suçu işlenebilirken; menapoz dönemini tamamlamış bir kadına karşı işlenen bu fiilleri, artık kasten yaralama hükümleri doğrultusunda değerlendirmek gerekecektir. Erkek için ise, her yaşta üreme fonksiyonu mümkün olduğundan erkeğe karşı her zaman bu suçun işlenmesi mümkündür. Meğerki üreme yeteneğini doğuştan veya sonradan kaybetmiş olsun. Yine söz konusu kısırlaştırma suçunun işlenmesiyle, suçun konusu olan kişinin üreme organlarında illaki bir zarar oluşacağından, bu suç bir zarar suçudur (Özgenç, 2015).

\section{Fail}

TCK m. 101/1'de düzenlenen kısırlaştırma suçunun faili yetkili hekimdir. Başka bir ifadeyle, bu suç özgü suç niteliğindedir. Aynı maddenin ikinci fikrasında (m.101/2) düzenlenen kısırlaştırma suçunun faili ise, yetkisiz kişilerdir. Başka bir ifadeyle, kısırlaştırılan kişi ve yetkili hekimler dışında herkes, bu suçun faili olabilecektir.

Koca ve Üzülmez (2013), TCK m. 101/2'de açıkça “yetkili olmayan bir kişi tarafindan" denilmesine rağmen, bu suçun failinin ancak yetkisiz hekimler olduğunu savunmaktadır. Yani bu suçun faili, illa bir hekim olmalı, fakat yetkisi bulunmamalıdır. Yine Koca ve Üzülmez'e göre, eğer normal bir vatandaş kısırlaştırma fiilini işlerse, kendisine ancak TCK m. 87/2(c)'den ceza verilmelidir. $\mathrm{Bu}$ görüşe katılmak kanaatimizce mümkün değildir. Açıkça kanun metninde, "yetkili olmayan bir kişi " demektedir. Kanun metnindeki "bir kişi”" ibaresini "bir hekim" olarak anlamalarının sebebini, kısırlaştırma suçunun ancak bir ameliyatla hastane ortamında işlenebileceğini düşündüklerinden kaynakladığı kanaatindeyiz. Oysaki pekâlâ bir tıp fakültesi öğrencisi, bir emekli doktor, bir hemşire hatta bir sağlık personeli bile, bir hastane ortamı içinde veya dışında, ilaç veya alet kullanarak kişilerin kısırlaştırmasını sağlaması mümkündür. Aynı şekilde fail ile mağdurluk sıfatı aynı kişide birleşemeyeceğinden, bir kimsenin kendi kendini kısırlaştırması filii cezalandırılamayacaktır.

\section{Mağdur}

$\mathrm{Bu}$ suçun mağduru ise, kendisine kısırlaştırma fiilinin tatbik edilen, yani kısırlaştırılan kişidir (Koca ve Üzülmez, 2013,). Bu kişi kadın veya erkek olabilir; fakat başta da ifade ettiğimiz üzere bu kişinin üreme yeteneğine haiz olması gerekmektedir. Dolayısıyla herkes bu suçun mağduru olamayacaktır. Keza faille mağdurluk sıfatı aynı kişide birleşemeyeceğinden, bir kimsenin kendi kendini kısırlaştırması fiili cezalandırılamayacaktır (Koca ve Üzülmez, 2013; Tezcan, Erdem ve Önok, 2014).

\section{Suçun Maddi Unsuru}

$\mathrm{Bu}$ suçun maddi unsurunu hareket, netice ve nedensellik bağı başlıkları altında incelemek gerekecektir.

\section{Hareket}

Kısırlaştırma suçunda hareket, bir kimsenin üreme yeteneğinin kaybedilmesine yol açmaktadır. Başka bir ifadeyle bu suç, bir kimsenin üreme kabiliyetini kaybetmesine yönelik işlenmektedir. Erkeğin cinsel organı testisler ve penisten oluşmaktayken; kadının cinsel organları, vajina, rahim, 
fallop tüpleri ve yumurtalıklardan oluşmaktadır (Simkin, Whalley, Keppler, Durham ve Bolding, 2011). İşte bunlardan birinin kaybıyla artık kişinin üreme yeteneğinden bahsedilemeyecektir. Dolayısıyla uygulamada, kısırlaştırma fiili, bunlardan en az birinin işlevsiz hale getirilmesine yönelik olmaktadir.

Türk Hukuku'nda, kısırlaştırma fiilinden sterilizasyonun kastedildiğini ve 2827 sayılı NPHK'da düzenlendiğini daha önce ifade etmiştik. Buna göre, NPHK'da düzenlendiği şekliyle kısırlaştırmadan, "erkek veya kadının cinsel ihtiyaçlarını tatmine engel olunmaksızın çocuk yapma yeteneklerinin giderilmesi"ni anlamak gerekecektir (NPHK, m.4/1).

Buradaki hareketin ne şekilde işleneceği kanuni tanımda belirlenmediğinden bu suç, serbest hareketli bir suç niteliğindedir (Koca ve Üzülmez, 2013). İcrai ve ihmali davranışla bu suçun işlenmesi mümkündür. Örneğin husumetinin olduğu hastasını tedavi niyetiyle ameliyata alıp kısırlaştırması fiilinde, kısırlaştırma suçu icrai davranışla işlenirken; hastaya sinirlenen hekimin bilahare prostat ameliyattan çıkan hastaya gereken tedavi tedbirlerini uygulamayarak kısırlaşmasının sağlanmasında, ihmal suretiyle kısırlaştırma suçu söz konusu olabileceği kanaatindeyiz.

Öğretide bir görüsse göre her ne kadar, kısırlaştırma işlemiyle, üreme yeteneğinin geri dönüşü olmaksızın kaybedilmesi gerektiği ifade edilse de (Hakeri, 2014; Tezcan, Erdem ve Önok, 2014), günümüz tıp teknolojisinde tekrar üreme yeteneğinin kazanıldığının örnekleri mevcuttur. 2008'de kurulmuş ve 2010'da faaliyete geçmiş Amerikan Kadın Hastalıkları ve Jinekologlar Kurulu (ACOG)'nun, 11.09.2015 tarihli raporuna göre; kısırlaştırma işlemleri, ilelebet çocuk yapma yeteneğini ortadan kaldıran bir müdahale olmadığı, ihtimali az da olsa, mikronluk müdahalelerle tekrar üreme yeteneğinin kazanılabildiği ifade edilmiştir (Ozansü, 2008). Dolayısıyla üreme yeteneği kaybolan kişinin aldığı tedavi sonucu tekrar üreme yeteneğine sahip olması, bu suçun oluşmasını engellememelidir (Koca ve Üzülmez, 2013). Tıp teknolojisinin ilerlemesiyle kısırlaştırma işlemlerinin olmamış hale getirilmesi kolaylaşacağından kanaatimizce, geçici süreli kişilerin üreme yeteneğinden yoksun bırakılması da, yaptırımsız kalmamalıdır. Bunun için bir düzenlemenin yapılması kanaatimizce ihtiyaç göstermektedir. TCK'nın kısırlaştırma başlıklı 100. maddesine şu şekilde bir üçüncü fikra eklenerek bu problemin çözüleceği kanaatindeyiz: "Kiş̧ilerin geçici nitelikte kısırlaştırılması halinde verilecek ceza yarı oraninda azaltılır."

Bununla birlikte, NPHK m. 4/2'de evli birinin kısırlaştırılması için eşinin rızasının gerekeceği ifade edilmiştir; fakat TCK'da düzenlenen kısırlaştırma suçunda eşinin rızası suçun unsurunda yer almadığından, eşinin rızası olmaksızın kişinin kısırlaştırılması bu suçu oluşturmayacaktır. Başka bir ifadeyle eşinin rızasının olmaması hali, kanun tarafından cezalandırılmaya layık görülmemiştir. Örneğin, aldatıldığını öğrenen bir doktorun, eşini rızası olmaksızın kısırlaştırması fiili, rızasız kısırlaştırma suçunu oluşturduğunda bir şüphe yoktur. Keza eğer fail yaralama kastıyla hareket edip işlediği fiille mağdur üreme yeteneğini kaybederse, TCK m. 87/2(c)'deki netice sebebiyle ağırlaştırılmış yaralama suçundan sorumluluğu söz konusu olacaktır.

Bunun yanı sıra NPHK'da, sterilizasyondan daha ağır bir işlem olan ve 'hadımlaştırma' olarak tanımladığımız kastrasyonun işlemi de düzenlenmekte olup TCK'nın 101. maddesi dışında kalmaktadır. Yani TCK, sadece kısırlaştırma fiilini suç olarak tanımlamışken, hadımlık fiilini suç olarak düzenlememiştir. Öğretide, hadımlaştırma niteliğindeki fiillerin nasıl cezalandırılacağına ilişkin üç farklı görüş mevcuttur. Bir görüşe göre, zorunlu bir kısırlaştırma söz konusu olduğundan TCK m. 101 kapsamında değerlendirilmelidir ki (Hakeri, 2014), bu görüşe katılmamaktayız. Çünkü hadımlaştırma fiili kısırlaştırma fiilinden daha ağır bir neticeye sahiptir ve çoğun içinde az vardır; ama azın içinde çok yoktur kuralınca hadımlaştırma kısırlaştırmadan ayrı ve daha ağır cezalandırılmalıdır. Diğer görüşe göre ise, kısırlaştırma ile kasten yaralamanın neticesi sebebiyle ağırlaşmış şeklinin fikri içtima halinde varlığını kabul etmek gerekmektedir (Koca ve Üzülmez, 2013). Katıldığımız görüşe göre ise, kasten yaralamanın neticesi sebebiyle ağırlaşmış halini (TCK, m. 87/2(c)) oluşturacağını düşünmekteyiz (Kiziroğlu, 2013; Ozansü, 2008). Eğer kısırlaştırma fiili mağdurun ölümüne yol açarsa, kasten yaralamanın neticesi sebebiyle ağırlaşmış halinden TCK m. 87/4 gereği, failin cezalandırılması gerektiği kanaatindeyiz (Ozansü, 2008). 
Netice

Kısırlaştırma suçu, neticeli bir suçtur. Kişinin üreme yeteneğini kaybetmesiyle bu suç tamamlanmış sayılacaktır.

\section{Nedensellik Băğ}

Kısırlaştırma suçunda nedensellik bağı, failin icra ettiği hareketler sonucu suçun kanuni tanımındaki neticenin gerçekleşmesini ifade etmektedir.

\section{Suçun Manevi Unsuru}

TCK m. 101'de düzenlenen kısırlaştırma suçları, ancak kasten işlenebilmektedir. Madde metninin 1. fikrasında ifade edilen "rızası olmaksızın" ibaresi ve 2. fikrada ifade edilen "rızası olsa bile" ibaresi bu suçun oluşabilmesi için, mağdurun rızasının olduğunun veya olmadığının fail tarafından bilinmesi gerektiğinden bu suç, ancak doğrudan kastla işlenebilecektir (Koca ve Üzülmez, 2013).

Suçun kanuni tanımında taksirle bu fiilin işlenebileceği düzenlenmediği için bu suç taksirle işlenemeyecektir. Fakat somut olayda taksirle yaralamadan sorumluluğun doğması mümkündür. Örneğin, objektif özen yükümlülüğe aykırı bir tıbbi müdahaleyle hastanın kısırlaşması sonucunda, taksirle kısırlaştırma suçu işlenemeyeceğinden artık taksirle yaralama hükümlerine göre fail sorumlu tutulacaktır. Eğer failin yaralama kastı olup yaralama fiili sonucu kişi üreme yeteneğini kaybetmişse, neticesi sebebiyle yaralama suçundan (TCK, m. 87/2(c)) dolayı failin sorumluluğu mümkün olacaktır.

\section{Suçun Hukuka Aykırılık Unsuru}

Bir suç düzenlemesinde failin cezalandırılabilmesi için, fiilin aynı zamanda hukuka aykırı olması gerekmektedir (Özgenç, 2015). Örneğin madde metninde geçen "rızası olmaksızın” ibaresi, bu suçun hukuka aykırılık unsuruna işaret ettiği kanaatindeyiz.

\section{Suçun Özel Görünüş Şekilleri}

$\mathrm{Bu}$ suçun özel görünüş şekillerini teşebbüs, iştirak ve içtima başlığı altında incelemek gerekecektir.

\section{Teşebbüs}

TCK m. 101'de düzenlenen kısırlaştırma suçları, neticeli bir suç olduğundan, kişinin üreme yeteneğinin kaybedilmesiyle bu suç tamamlanacaktır. Dolayısıyla bu suça teşebbüs; ancak icra hareketleri başladıktan sonra failin elinde olmayan nedenlerle neticenin gerçekleşmemesi, yani kişinin üreme yeteneğinin kaybedilmemesi durumunda söz konusu olacaktır. Örneğin yetkili hekim tarafından, bayıltılma öncesi rutin gibi gösterilen ameliyata hazırlık için yapılan testler, ameliyat anına kadar yapacağ 1 tıbbi hazırlıklar, hazırlık hareketi niteliğinde olacakken; habersiz bayıltılıp ameliyatın başlamasıyla, 'rızasız kısırlaştırma' suçunun icra hareketleri başlamış sayılacaktır. Bu ameliyatın başarısız olması ya da bir baskın sonucu ameliyatın yarıda kalması durumunda mağdur üreme yeteneğine sahip olarak kalırsa, işlenen fiiller kısırlaştırma suçuna teşebbüs niteliğinde olacaktır (Koca ve Üzülmez, 2013).

Eğer icra hareketlerine başlayan fail, kısırlaştırma fiilinin tamamlanmasından gönüllü olarak vazgeçerse, 'gönüllü vazgeçme' müessesesini düzenleyen TCK'nın 36. maddesi gereği, faile ceza verilmeyecektir. Eğer o ana kadar ki, fiiller bağımsız suç teşkil ediyorsa sadece o suçtan faile ceza verilecektir. Örneğin, ameliyat tamamlanmadan fail gönüllü vazgeçerse, kasten yaralamadan sorumluluğu söz konusu olabilecektir. 


\section{İştirak}

TCK'nın 101. maddesinde düzenlenen kısırlaştırma suçlarına hem fail sıfatıyla hem de şerik sifatıyla katılmak mümkündür.

Íçtima

İçtima konusunu bileşik suç, fikri içtima, normların görünüşte içtimaı ve gerçek içtima başlıkları altında incelemek gerekecektir.

\section{Bileşik Suç}

TCK m. 101'de düzenlenen kısırlaştırma suçuyla ilgili olarak, bileşik suç düzenlemelerinin mevcut olduğu kanaatindeyiz. Örneğin, TCK m. 76'da düzenlenen soykırım suçunun seçimlik hareketlerinden biri de, bir planın icrası kapsamında bir grubun kısmen veya tamamen yok edilmesi maksadıyla, 'grup içinde doğumlara engel olmaya yönelik tedbirlerin alınması'dır (TCK, m. 76/1(d)). Dolayısıyla bu maksatla, yetkili hekim veya hekimlerin bir gruba karşı işleyecekleri sistematik kısırlaştırma fiilleri, soykırım suçunun unsuru içerisinde bir seçimlik hareket olarak mütalaa edileceğinden, bileşik suç hükümleri gereği ayrıca kısırlaştırma suçundan sorumlulukları söz konusu olmayacaktır.

Keza TCK m. 87/2(c)'de, kasten yaralama suçunun neticesi sebebiyle ağırlaşmış haline yer verilmiş olup kasten yaralama neticesinde kişinin 'çocuk yapma yeteneklerinin kaybolmasına' neden olma hali düzenlenmiştir. Dolayısıyla failin yaralama fiili, mağdurun kısırlaşmasına sebep olmuşsa ayrıca kısırlaştırma fiilinden faile ceza verilmeyecektir.

\section{Zincirleme Suç}

Söz konusu kısırlaştırma suçlarında, kanaatimizce zincirleme suç hükümlerinin uygulanması mümkündür (Artuç, 2008; Bakıc1, 2010). Örneğin rızası olmaksızın geçirdiği sterilizasyon ameliyatıyla yumurta kanalı bağlanan kadının, bilahare tekrar cerrahi müdahaleyle kanalının açılması mümkündür. İşte ilk ameliyatla kendisine karşı kısırlaştırma suçu işlenen kadının, tekrar üreme yeteneğine sahip olabilme imkânı olmasından bahisle, tekrar aynı kişi tarafindan aynı ameliyata maruz kalması durumunda birden fazla kısırlaştırma suçunun farklı zamanlarda işlenmesi söz konusu olacağından, zincirleme suç hükümleri uygulama alanı bulacaktır.

\section{Fikri İçtima}

TCK m. 101'de düzenlenen kısırlaştırma suçlarında, fikri içtima hükümlerinin uygulanması mümkündür. Mesela, aynı ameliyatla rızası olmaksızın gebe kadının rahmi alınmak suretiyle, hem gebeliği sonlandırılmış hem de kısırlaştırılmış olabilmektedir. Bu durumda TCK m. 44/1 kapsamında, en ağır cezayi gerektiren suçtan, yani çocuk düşürtme suçundan TCK m. 99/1 gereği, faile ceza verilmesi yoluna gidilmelidir.

\section{Normların Görünüsțte İçtimal}

Söz konusu kısırlaştırma suçlarının, hukuk mevzuatımızda yaptırıma bağlanmış başka ilgili düzenlemesi olmadığından, normların görünüşse içtimaı mümkün gözükmemektedir.

\section{Gerçek İçtima}

TCK m. 101'de düzenlenen kısırlaştırma suçları bağlamında, mesela arka arkaya yapılan ameliyatlarla birden fazla kişinin rızasız kısırlaştırılmasında, her bir ameliyatla gerçek içtima gereği, ayrı tamamlanmış kısırlaştırma suçlarından sorumluluk söz konusu olacaktır. 


\section{Hukuka Uygunluk Nedenleri}

Hukuka uygunluk nedenlerini, kanun hükmünü yerine getirme, meşru savunma, hakkın kullanılması, ilgilinin rızası başlıkları altında incelemek gerekecektir.

\section{Kanun Hükmünü Yerine Getirme}

TCK m. 101'de düzenlenen kısırlaştırma suçları bağlamında, bir hukuka uygunluk nedeni olarak 'kanun hükmünü yerine getirme' müessesesinin uygulama alanı bulması mümkün gözükmemektedir. Gerçekten de NPHK, "Sterilizasyon ameliyatı tıbbi sakınca olmadiğı takdirde reşit kişinin isteği üzerine yapılır” (m. 4/2) demek suretiyle, reşit kişilerin isteği üzerine kısırlaştırılmalarını düzenlemiştir. Dolayısıyla, ancak bu kapsamda yetkili hekim tarafından gerçekleştirilen kısırlaştırma fiillerinin herhangi bir cezai sorumluluğu olmayıp hukuka uygun kabul edilecektir.

\section{Meșru Savunma}

Rızasız kısırlaştırma suçu bakımından, 'meşru savunma' kurumunun uygulama alanı bulması teorik olarak mümkündür. Örneğin haksız bir saldırıyı gerçekleştiren kişiye aynı orantıda karşılık veren mağdurun fiili, saldırıyı başlatanın kısırlaşmasına sebebiyet verebilir, mesela cinsel organlarına aldığ 1 darbe sonucu kişi, üreme yeteneğini kaybetmiş olabilir. Burada gerçekleştirilen fiil, hukuka uygun kabul edileceğinden TCK m. 25/1 gereği, kısırlaştırma suçundan sorumluluk söz konusu olmayacaktır.

\section{Hakkın Kullanılmast}

TCK m. 101'de düzenlenen kısırlaştırma suçları bağlamında, bir hukuka uygunluk nedeni olarak 'hakkın kullanılmasının' uygulama alanı bulması mümkün gözükmemektedir. Gerçekten de NPHK'ca her reşit kişiye ancak rızaya dayalı kısırlaştırma hakkı tanıdığından (m. 4/2), bu kapsamda kullanılarak kişinin kısırlaştırılmasında, kısırlaştırılan kişi açısından herhangi bir cezai sorumluluk olmayıp bir hakkın kullanılmasından bahisle söz konusu fiil, hukuka uygun kabul edilecektir.

\section{İlgilinin Rıası}

NPHK kapsamında, kişinin kendi istek ve rızasıyla, yetkili hekim tarafından kendisinin kısırlaştırmasını kabul etmesi, bir hukuka uygunluk sebebi olduğundan artık TCK m. 101'in uygulanması söz konusu olmayacaktır. Tabii ki, bunun için kişinin rızasını serbest olarak özgürce açıklaması, tıbbi bir sakıncanın olmaması ve rızanın baştan itibaren bulunması gerekecektir (Tezcan, Erdem ve Şentürk, 2014; NPHK, m. 4/2).

\section{Kusurluluğu Kaldıran Nedenler}

Kusurluluğu kaldıran nedenleri, zorunluluk hali, yetkili amirin emrini yerine getirme, cebir veya tehdit, hata başlıkları altında incelemek gerekecektir.

\section{Zorunluluk Hali}

TCK m. 101'de düzenlenen söz konusu kısırlaştırma suçları bakımından tıbbi zorunluluk halinde uygulanan kısırlaştırma işlemi, hukuka uygun kabul edilecektir. Örneğin hastanın bilincinin kapalı olduğu bir durumda, tıbbi bir zaruret nedeniyle annenin rahminin alınması ve bu suretle kişinin kısırlaştırılması fiili, kanaatimizce zorunluluk halinin bir örneği sayılacaktır ve hekimin sorumluluğu söz konusu olmayacaktır.

Nitekim NPHK'nın 4. maddesinin 3. fikrasında, “...bir ameliyatın seyri sirasında tıbbi zaruret nedeniyle bir hastalığın tedavisi için kastrasyonu gerektiren hallerde, kişinin rızasına bakılmaksızın kastrasyon ameliyesi yapılabilir" demek suretiyle kastrasyondan daha az haksızlık muhtevasına sahip yapılacak kısırlaştırma işlemlerini de bu cümleden saymak mümkündür (Tezcan, Erdem ve Önok, 2014, s.320; Koca ve Üzülmez, 2013, s.282). 


\section{Yetkili Amirin Emrini Yerine Getirme}

Rızasız kısırlaştırma suçu bakımından 'yetkili amirin emrini yerine getirme' müessesesinin uygulama alanı mümkün gözükmemektedir. Gerçekten de yetkili bir hekim, NPHK'ca hak olarak tanınan kısırlaştırma ameliyatına karar verse dahi, burada hekim bu ameliyata kendisi karar vermektedir, ayrıca başhekimlik gibi bir üst merciin emri söz konusu olmamaktadır (13.01.1960 t. ve 12578 s. T1bbi Deontoloji Tüzüğü, m. 6).

\section{Cebir Veya Tehdit}

Bir suç düzenlemesi bakımından kusurluğu kaldıran neden olarak cebir veya tehdit müessesesinin koşulları gerçekleşirse, karşı koyulamayan veya kurtulamayan cebir veya tehdidi uygulayan kişi fail sayılacaktır (TCK, m. 28/1). Dolayısıyla mesela başka bir ameliyat için bayıltılan kişinin kısırlaştırılması için hekimin başına silah dayanarak ölüm tehdidinde bulunan A'nın fiilinde, kısırlaştıran hekime değil, tehditte bulunan A'ya rızasız kısırlaştırma suçundan ceza verilecektir.

\section{Hata}

TCK m. 101'de düzenlenen kısırlaştırma suçları bakımından kusurluluğu kaldıran bir neden olarak hata müessesesinin koşulları gerçekleşirse uygulanması mümkündür. Hata kastı kaldırdığından ve rızasız kısırlaştırma suçu da ancak kasten işlenebileceğinden, hata halinde suç oluşmayacaktır. Örneğin herhangi bir hastanın eczaneden ilaçlarını alırken, eczacı kişinin doktorun yazısını okuyamayıp yazdığı yazıya çok benzer kişinin kısırlaşmasını sağlayacak başka bir ilaç vermesi durumunda, bu ilacı kullanan kişinin üreme hakkından yoksun kalmasında, eczacının kısırlaştırma suçunda sorumlu olması söz konusu olacak mıdır? Kanaatimizce burada her ne kadar yetkisiz kişi olan eczacının hareketiyle, kişinin kısırlaşması arasında bir illiyet bağı kurulabiliyor olsa da, kısırlaştırma suçunun maddi unsurlarında bir hata söz konusudur (TCK, m. 30/1). Şu halde, eczacının dikkatsiz ve özensiz olmasından bahisle, söz konusu hatasında taksirinden söz edebilsek de, taksirle kısırlaştırma suçu düzenlenmediğinden, bu suç oluşmayacaktır; fakat taksirle yaralamadan failin sorumluluğu söz konusu olmalidır.

\section{Sonuç, Tartışma ve Öneriler}

Kişilerin üreme ve neslini devam ettirebilmesi açısından kısırlaşma hakkının, hangi noktada mutlak olarak kişiye verileceğinin tespiti, o ülkenin geleceği açısından önem arz etmektedir. Hukuk sistemimizde bu nokta, kişinin reşit olması olarak öngörülmüştür. Bu noktaya gelmiş reşit kişi, buna rıza göstermiş olmalı ve "üreme hakkından yoksun kalmak istiyorum, risklerini biliyor ve kabul ediyorum" diyebilmelidir. Bunun için ise, kişinin yeterli bilgi düzeyine gelebilmesi için, gerekli eğitime ve danışmanlık hizmetine ulaşabilmesi gerekmektedir. Burada öncelikle bir uzman danışman görüşü almanın ve ilgili tıbbi işlemin hem fiziksel hem de ruhsal açıdan etki ve sonuçlarını öğrenmenin zorunluluğunun olmamasını ve bir düşünme süresinin de bulunmamasını hukuk sistemimizde bir eksiklik olarak görmekteyiz.

Öğretide, beden bütünlüğü, yaralama suçu ile korunduğundan, kısırlaştırma suçunun tanımlanmasına gerek bulunmadığı ileri sürülmektedir (Tezcan ve Önok, 2014, s.312; Hakeri, 2015, s.883). Bu görüşe göre, kişilerin vücutlarına müdahale, kısırlaşmalarına yol açarsa, TCK m. 87/2'nin (c) bendi kapsamında faili cezalandırmak mümkündür. Bu görüşe katılmak kanaatimizce mümkün değildir. İlk olarak, TCK'da kişilerin vücut bütünlüğünü koruyan ve 'yaralama' suçundan başka ilgili suç düzenlemeleri vardır ve bu düzenlemelerin gerekli olduğunda da şüphe yoktur. Örneğin, TCK, m. 90: Insan Üzerinde Deney, TCK m. 94: İşkence, TCK m. 96: Eziyet, TCK, m. 99: Çocuk Düşürtme, TCK, m. 100: Çocuk Düşürme gibi. İkinci olarak, fail doğrudan kısırlaştırmak amacıyla da pekâlâ hareket edebilir. Bazı ilaçlarla sadece üreme duyu ve organları tahrip edilebilir. Her zaman kısırlaştırma, yaralama suçunun neticesi sebebiyle ağırlaşmış halini oluşturmaz. Üçüncü olarak, belki de en önemlisi, kişileri kısırlaştırmak fiiliyle yaralamayı genel itibariyle bir tutmak; vücut dokunulmazlığı hakkı ile üreme hakkını bir tutmak gibi doğru olmadığına inandığımız açıklamalardır. 
Dolayısıyla kanun koyucunun izlediği suç siyaseti gereği, kişilerin üreme hakkını korumak için özel suç tanımları düzenlemesi bir çelişki arz etmemektedir (Koca ve Üzülmez, 2013, s.272).

Aynı şekilde TCK'da 'hadımlık' veya tıp biliminde 'kastrasyon' işleminin, kısırlaştırma suçu kapsamında düzenlenmesi gerektiği kanaatindeyiz. Yani hadımlaştırma gibi ağır bir müdahalenin TCK'da bir nitelikli hal olarak düzenlenmesinin fayda arz edeceği düşüncesindeyiz. Aynı şekilde kısırlaştırma suçunun kanuni tanımında, kısırlaştırma işleminin geçici olması durumunun da düzenlenip cezayı azaltan bir neden olarak kaleme alınması gerektiği kanaatindeyiz. $\mathrm{Bu}$ mülahazalarımızla TCK'nın 100. maddesinde düzenlenen kısırlaştırma suçunun şu şekilde değiştirilmesinin daha uygun olacağı kanaatindeyiz.

\section{Üreme Hakkından Yoksun Bırakılması}

Madde 100: (1) Bir kimseyi rızası olmaksızın kalıcı olarak üreme hakkından yoksun bırakan kişi, dört yıldan on yıla kadar hapis cezasıyla cezalandırllır. Geçici olarak üreme hakkından yoksun bırakılması halinde, verilecek ceza yarı oranından üçte bire kadar azaltılır.

(2) Birinci fikrada yazılan fiiller, yetkisiz kişi tarafindan işlenmesi halinde verilecek cezalar üçte bir oranında artırllır.

TCK m.101'de düzenlenen 'kısırlaştırma suçu' yerine 'üreme hakkından yoksun bırakılması' başıı̆ını tercih etmiş bulunmaktayız. Üreme hakkından yoksun kalmanın kalıcı durumda olmasından 'kastrasyon ve kimyasal kısırlaştırma'yı kastetmekle birlikte, geçici durumda yoksun kalmadan ise, 'cerrahi kısırlaştırmayı veya daha az nitelikteki hareketleri'ni (örneğin bir hekimin, çocuk istememesinden bahisle eşine rutin kontrol gibi gösterip rahmine bir spiral takması) kastetmekteyiz. Hemen belirtelim ki, böyle bir ayrımda bulunma nedenimiz sürekli gelişme halinde olan tıp teknolojisidir. Belki ileride kastrasyon işleminin bile kök hücre ya da yapay hücre tedavileriyle geri dönüşü mümkün olabileceğinden bahisle, bu ayrımın daha isabetli olacağını düşünmekteyiz.

Keza devletlerin geleceklerini etkileyen bu fiillerin sistematik bir şekilde bir gruba karş1 işlenmesi hali, soykırım suçunu oluşturacağı gerek uluslararası düzenlemelerde gerekse iç hukukta kabul edilmektedir. Örneğin, 09.12.1948 tarihinde Birleşmiş Milletler nezdinde hazırlanan ve 12.01.1951'de yürürlüğe giren 'Soykırım Suçunun Önlenmesine ve Cezalandırılmasına Dair Sözleşme'nin m.2/1(d) bendinde, "Grup içinde doğumları engellemek amactyla tedbirler almak" soykırım suçları arasında sayılmıştır. Nitekim 5237 sayılı TCK (m.76/1(d)'da, bu fiil, soykırım suçunun seçimlik hareketleri arasında düzenlenmiştir. Dolayısıyla bu düzenlemelerle, bir grubun sistematik bir şekilde kısırlaştırılmasının soykırım suçunu oluşturacağında şüphe yoktur. 


\section{Kaynaklar}

Akbaba, Z. B. (2009). Kimyasal hadım yönteminin anayasaya uygunluğu-I. Türkiye Barolar Birliği Dergisi, 81, 7-19.

Akyıldız, S. (2010). Kısırlaştırma operasyonlarında hekimin aydınlatma yükümlülüğü. III. Sağllk Hukuku Kurultayl, Ankara Barosu, Ankara.

Alpaslan, B. (2012). Türk ceza kanununa göre kısırlaştırma (sterilizasyon) suçu. İstanbul Barosu Dergisi, 86(4), 187-199.

Artuç, M. (2008). Kişilere karşı suçlar. Ankara: Seçkin Yayıncılık.

Bakıc1, S. (2010). 5237 sayıl yasa kapsamında ceza hukuku özel hükümleri. Ankara: Adalet Yayınevi.

Çokar, M. (2008). Kürtaj. İstanbul: Babil Yayınevi.

Erşahin, M. (2002). İslam hukuku açısından aile planlaması. Selçuk Üniversitesi Sosyal Bilimler Enstitüsü, Yüksek Lisans Tezi, Konya.

Hafızoğulları, Z. ve Özen, M. (2015). Türk ceza hukuku özel hükümler kişilere karşı suçlar. Ankara: Us-A Yayıncilık.

Hakeri, H. (2015). Tip hukuku (10. Baskı). Ankara: Seçkin Yayıncılık.

Hakeri, H. (2012). Türk hukukunda kürtaj ve sezaryen, kadının vücut bütünlügüü üzerine hukuki ve tıbbi yaklaşım paneli. İstanbul: İstanbul Barosu Yayınları.

Kiziroğlu, S. K. (2013). Türk ceza hukukunda çocuk düşürtme, düşürme ve kısırlaştırma suçları. Marmara Üniversitesi Hukuk Fakültesi Hukuk Araştırmaları Dergisi, 19(2), 187-211.

Koca, M. ve Üzülmez, İ. (2013). Türk ceza hukuku özel hükümler. Ankara: Adalet Yayınevi.

Mehtaji, S., Jadwani, K. ve Goyal, V. (1977). Chemical Sterilization With Quinacrine. Bombay: India Frp Contributors.

Ozansü, M. C. (2008). Kısırlaştırma suçu, tıp ceza hukukunun güncel sorunları. Ankara: Türkiye Barolar Birliği Yayınları.

Özgenç, İ. (2015). Türk ceza hukuku genel hükümler. Ankara: Seçkin Yayınclık.

Pastner, B. (2012). Suçlarda Erkek Faillerinin Hadım Edilmesi, III. Sağlık Kurulu Kurultayı. Ankara: Ankara Barosu.

Shih, G., Turok, D. K. ve Parker, W. J. (2011). Vasectomy: The Other (Better) Form Of Sterilization, Contraception, 83, 311-400.

Simkin, P., Whalley, J., Keppler, A., Durham, J. ve Bolding, A. (2011). Hamilelik, doğum ve bebek.

Taşçı, A. İ. (1998). Nüfus kontrollerinin arka planı. Tüm Yönleriyle Uluslararası Aile Planlaması Sempozyuтu, İstanbul.

Temel, E., (2010). Alman hukukunda sterilizasyon uygulamalarından kaynaklanan hukuksal sorunlar. III. Sağlık Hukuku Kurultayı, Ankara: Ankara Barosu.

Tezcan, D., Erdem, M. R. ve Önok, R. M. (2014). Teorik ve pratik ceza özel hukuku (11. Bask1). Ankara: Seçkin Yayıncılık. 
Tezcan, D., E., Mustafa R. ve Şentürk, C. (2014). Ceza hukuku özel hükümler pratik çalışmalar, (3. Baskı), Ankara: Seçkin Yayıncılık.

Toroslu, N., (1968). Ceza hukukunda zaruret hali. Ankara: Sevinç Yayıncılık.

Tunç, H., Bilir, F. ve Yavuz, B. (2009). Türk anayasa hukuku, Ankara: Asil Yayın Dağıtım.

World Health Organization (Who), (2014) Eliminating forced, coercive and otherwise involuntary sterilization, New York: Publications Of The World Health Organization.

Yenidünya, A. C. ve Yaşar, Y. (2013). Kastrasyon cinsel suç faillerine uygulanabilecek uygun bir yaptırım mıdır?, Türkiye Adalet Akademi Dergisi, 4(14), 181-211. 


\section{Extanded Abstract}

The right of a person to continue reproduction and generation is as fundamental as the right to life. Because people who have the right to reproductive can continue their generation, they will have the right to live. In other words, the right to life will also become dysfunctional, since the survival of the right to reproductive failure can not be ensured. With these considerations, crime definitions for the acts of sterilization to protect the reproductive right in criminal law are organized. It is also stated that the sterilization crime, which is organized in Article 101 of the Turkish Criminal Code numbered 5237, guarantees the right to reproduction and that this regulation of the teaching has been inadequate. For the definition of this crime, it is necessary that the castration should be added; criticism has been made that the legal definition of the crime does not comply with the law. However, the Population Planning Law no. 2827 gives the right to sterilize every adult person. Here, for the protection of this right, even if the person is unwittingly sterilized or resigned, the fact that this act is committed by unauthorized persons is regulated as a terrorizing act in the Turkish Criminal Code.

5237 Turkish Penal Code Article 101 of the sterilization organized crime, but guarantees the right of reproduction, is expressed in the doctrine is not sufficient. Both must be in castration consequently the definition of this crime; as well as the law on technical legal definition of the crime are brought criticism that it is not appropriate. However, No. 2827 Law on Population Planning every adult person is granted the right to sterility. That's for the protection of this right, even if people find the sterilized without consent or acquiescence of, the actual processing of the unauthorized status of the Turkish Criminal Code offense is designed as sterilization.

'Sterilization' with 'sterilization' or widespread expression means that the male or female is removed from the operation by reproductive ability. In this process, sexual abuse is not eliminated, while the reproductive ability is abolished. That is, in the process of sterilization, the sexual desire and desire of the person continues while the reproductive ability is rising.

Today sterilization is one of the most common forms of contraception for couples. It is a reliable and effective means of permanently controlling fertility when informed and made according to the appropriate clinical standards with the recipient.

Although it is expressed in the teachings that the reproductive ability is lost without sterilization, there are examples of the ability to reproduce in today's medical technology.

This medical procedure is carried out in two ways: 'surgical sterilization' and 'chemical sterilization'.

Since surgical sterilization is applied separately to male and female, it is necessary to examine under two separate headings.

Surgical sterilization in males is performed by 'vasectomy' (tying the tubes / tying the cord). In this method, the sperm is cut off by suture surgery, preventing the transfer of sperm into the urinary tract from the testes. Also in this method, the sperm channels are cut from both ends and the cut ends are connected or plugged with the help of electric heaters.

Surgical sterilization in women is performed by a surgical intervention called 'tube ligation'. With this operation, connecting the tubes, ie the egg channel, prevents the egg from reaching the uterus and the sperm cell joining with the egg cell.

Although it is necessary to have 'vasectomy', it is important that the person to be neutered is sufficiently illuminated in the 'tube ligation' process. Because it is a medical reality that both processes have significant side effects. Especially for patients with heart disease, respiratory insufficiency, hypertension, diabetes, impaired clotting, anemia and obesity, sterilization should not be the first option and any complications that may be encountered should be clearly articulated. For example, for a breastfeeding mother, it should be clearly stated that tube ligation will affect the baby by betting on the maternal use of the anesthetic used.

'Chemical sterilization' has been used as a medical method in the past to prevent the spread of important infectious diseases and it is a medical procedure that enables the end of the reproductive ability of the person by means of chemical substances given to the body.

This procedure is performed in women by placing tablets in the uterus with chemical effect and destroying the uterus and the tubes in the form of burns; More men are using vaccination to stop sperm production. Attention, here too, sexual nudity is not eliminated. Whether the uterus or tubules have been destroyed by the woman, or the male, the production of the sperm has been stopped, but the 
sexual dysfunction continues to occur in the person. However, it is not a highly preferred method because of the large number of side effects of the chemical substances used.

The Concept of Hadding is similar to the Sterilization process, but unlike it, there is a process in which the sexual dysfunctions are removed with their fertility; It is also called 'castration' or 'castration' by medical expression.

Although it is stated in teaching that, with the process of sterilization, reproductive ability must be lost without recycling, there are examples of how reproductive ability is gained in contemporary medical technology. Therefore, the ability of a person to lose reproductive ability to have the reproductive ability of the treated end result should not prevent this from happening. Since medical technology has made it easier to make sterilization procedures progressive, it should not be sanctioned to deprive transient people of their reproductive ability. We need to make an arrangement for this. 